\title{
Retraining Programmes for Teacher Productivity in Public Secondary Schools in Bayelsa State: Planning Implications
}

\author{
Ohia Adanma Ngozi , Odenefe Sam-Odumo
}

\begin{abstract}
The paper examined managing retraining programmes for teacher productivity in public secondary schools in Bayelsa State. Two research questions and two hypotheses guided the study. The design was a descriptive survey with a population of 191 principals and 3,483 teachers in 191 public secondary schools, giving the numerical strength of the population as 3,674 . Using a stratified random sampling technique, the sample size was $367(10 \%)$ made up of 19 principals and 348 secondary school teachers. The instrument was a researchers'- structured 18-item questionnaire titled "Managing Retraining Programmes for Teacher Productivity Questionnaire (MRPTPQ). The response mode was in line with the four-point Likert scale. The instrument was validated by three experts in the area of measurement and evaluation. The internal consistency was established using Cronbach alpha method which yielded a reliability index of 0.76 . The findings of this study showed that while retraining programmes have introduced teachers to new teaching methodologies and technologies, the frequency of these programmes is limited by the availability of funds. The paper concluded that for teachers to be adequately informed and productive, workshops and seminars should be given priority in public secondary schools in Bayelsa State. The recommendations include: retraining programmes should be available in Bayelsa State secondary schools in order to continually improve teacher productivity, vice principal academics and others assigned with the duty of organizing workshops for teachers should ensure that teachers are periodically engaged in various workshop sessions in order for teachers' productivity to be constantly improved.
\end{abstract}

Index Terms - Managing retraining programmes, teacher productivity, secondary schools

\section{INTRODUCTION}

The most important asset in any system are the human resources. The educational system is not an exception as the teachers seem to be the most valuable assets. The effectiveness of the educational system therefore depends largely on the productivity of the teachers who are the interpreters and transmitters of desirable attitudes, knowledge, skills and values of the society. Undoubtedly, the dynamic and evolving nature of the educational system requires continuous review and update which demands a corresponding retraining of the teacher in order to meet up

Ohia Adanma Ngozi (Ph.D.), Faculty of Education, University of Port Harcourt, Rivers State, Nigeria

Odenefe Sam-Odumo, PG student, Faculty of Education, University of Port Harcourt, Rivers State, Nigeria with the dynamic educational trend. This ultimately is to make the teacher productive.

Training is a systematic process of altering the behaviour, knowledge and skills of the employee to ensure productivity and achievement of organizational goals. Whereas, retraining is the process whereby the already trained personnel is exposed to more training for a better or enhanced working ability. Retraining programmes are those initiatives that allow the teacher to engage in the process of learning, to strengthen their knowledge, skills, abilities and aptitudes. According to Igwe,(2002) there are profitable results in exposing teachers to retraining programmes as it promptly solves the problem of update of knowledge. Stressing further that there is a great disparity between trained and retrained teachers in their output performance.

In secondary schools, retraining for teachers could be done while on the job; and it is via these retraining programmes that the teachers get updated for effective duties in order to cope with the evolving trend in the school system. In secondary schools, retraining most times is either a response to an event such as a change in the curriculum; change in teaching aid, or as a result of the need to close a knowledge gap in teaching methodologies or behavioural imbalances. In the Nigerian National Policy on Education, the basis for teacher retraining is in recognition of the changes in methodology and in the curriculum, promotion of professional growth in line with global changes (FGN, 2013). These retraining programmes could be in form of workshops and seminars.

Workshops are small class sessions which afford teachers the opportunity to exchange ideas, foster good spirit and relationship among professional colleagues, and acquaint them with new and special problems that might confront them in their schools. According to Hill (2012) it can be inferred that good teachers become great teachers by participating in conferences, workshops, and continuing education to enable them go beyond the call of duty and beyond the textbook to acquire that extra help in technology for their students.

Teacher-based workshops are organized with the intention of rubbing minds together on current and other issues that could lead to improvement in teaching and learning situations in the school. (Nkang, 2012). Hence, it can be deduced that during workshop sessions, the emphasis is on problem-solving, hands-on training, and the involvement of the participants. The participants in a workshop session stand to benefit from accumulation of resource materials, evidence of personal growth after the workshop session(s) and an 
obvious positive change in their professional outlook.

Workshop could therefore be categorized as a teacher retraining program as its primary objective is the professional development of the teacher by creating a platform for them to share ideas and help each other propagate new ideas that can be beneficial to all. These workshop sessions could be of different categories some of which according to Educational Initiatives Working Paper - Issue 13 (2010, p.7) are: Curriculum workshops and Subject workshops.

Curriculum workshops give schools an exposure to skill-based curriculum and assessment. It helps schools enhance the existing systems and procedures from a fact-based, rote-oriented curriculum to a skill-based curriculum which provides teachers with actual hands-on experience. It also fosters a skill based approach and helps teachers inculcate the learning into their daily work through appropriate activities, worksheets and other related elements. This approach makes the learning process more interactive and student-centred.

Subject workshops on the other hand, help teachers understand the learning objectives of specific subjects like Language, Mathematics and Science. The workshops motivate teachers to reflect on the importance of making learning applicable and closer to real life context. Many creative ideas are shared on how to develop not-too-expensive teaching aids. This workshop serves as a platform for teachers to explore various tools through discussions, case studies and information from diverse places.

A seminar which is also a form of retraining programme, which brings small groups together for meetings, emphasizing some particular subjects, expecting every participant to be involved (Wikipedia). As affirmed by Palappallil, Sushama, and Ramnath (2016) a seminar is a small group of teaching-learning (T-L) session in which the participants discuss under the guidance of an expert.

A teacher oriented seminar session is more like an instructor-led session with visual aids. The instructor has prepared concepts and techniques to present and discusses using a combination of visual materials, interactive tools or equipment, and demonstrations. It includes some take home materials for the participants that relates to the lecture.

The duty of the teacher is to impact knowledge and the ultimate goal of impacting knowledge is to achieve learning. When learning is achieved then the act of teaching can be said to be productive. If the teaching was done and learning was not achieved then teaching was not productive.

\section{STATEMENT OF THE PROBLEM}

The future of the present young generation and next generation of leaders is highly dependent on the quality of mentoring and knowledge available via the teacher to the learner in our educational system. Surprisingly, public secondary school teachers in Bayelsa State seem not to be as productive as is expected of them. Could it be that the teachers in rural and urban located schools require more training and re-training programmes to ensure that their instructional delivery is improved? Could it also be that the already existing teacher retraining programmes are not properly managed? These constitute the problem of this study.

\section{PURPOSE}

The purpose of this study is to review some retraining programmes that can be implemented to achieve teacher productivity in secondary schools in Bayelsa State. Specifically, the study sought to find out:

1. The extent to which workshops impact teacher productivity in urban and rural secondary schools in Bayelsa State.

2. The extent to which seminar has contributed to teacher productivity in urban and rural secondary schools in Bayelsa State.

\section{RESEARCH QUESTIONS}

1. What is the extent to which workshops impact teacher productivity in public secondary schools in Bayelsa State?

2. To what extent do seminars enhance teacher productivity in public secondary schools in Bayelsa State?

\section{HYPOTHESES}

1. There is no significant difference in the mean ratings of the opinions of male and female principals and teachers on the extent to which workshops impact teacher productivity in public secondary schools in Bayelsa State.

2. There is no significant difference in the mean ratings of the opinions of principals and teachers in urban and rural public secondary schools on the extent to which seminars enhance teacher productivity in Bayelsa State.

\section{METHODOLOGY}

The research design for this study was a descriptive survey because the study examined the retraining programmes status quo with regard to teacher productivity in secondary schools in Bayelsa State. The numerical strength of the population was 3,674 made up of 191 principals and 3,483 teachers. Using stratified random sampling technique, the sample size was 367 (10\%) made up of 19 principals and 348 teachers. A structured questionnaire titled Managing Retraining Programmes for teacher Productivity Questionnaire (MRPTPQ) was used as the research instrument. The rating scale of the instrument was in line with the modified 4-point

Likert scale:

$\begin{array}{ll}\text { Very High Extent (VHE) - } & 4 \text { points } \\ \text { High Extent (HE) - } & 3 \text { points } \\ \text { Low Extent (LE) - }- & 2 \text { points } \\ \text { Very Low Extent (VLE) - } & 1 \text { point }\end{array}$

The instrument was validated by experts and reliability was ascertained using the test-retest method in a pilot study and the internal consistency established using Cronbach Alpha method which yielded a reliability index of 0.76 . Data were analysed using mean and standard deviation (SD) to answer the research questions while 


\section{RESULTS AND DISCUSSIONS}

Research Question 1: What is the extent to which workshop influences teacher productivity in public secondary schools in Bayelsa State?

Table 1: Weighted mean, standard deviation and rank order statistics of respondents in urban and rural schools on the extent to which workshop influences teacher productivity in Bayelsa State

\begin{tabular}{|c|c|c|c|c|c|c|c|c|}
\hline \multirow[t]{2}{*}{$\mathrm{S} / \mathrm{N}$} & & \multicolumn{2}{|c|}{$\begin{array}{l}\text { Urban } \\
\text { principals and } \\
\text { teachers }=237\end{array}$} & \multicolumn{2}{|c|}{$\begin{array}{l}\text { Rural } \\
\text { principals and } \\
\text { teachers }=130\end{array}$} & \multirow[t]{2}{*}{$\begin{array}{l}\text { Mean } \\
\operatorname{set}\left(x_{1} x_{2}\right)\end{array}$} & \multirow[t]{2}{*}{$\begin{array}{l}\text { Rank } \\
\text { order }\end{array}$} & \multirow[t]{2}{*}{ Remarks } \\
\hline & & $\overline{\mathrm{X}}_{1}$ & $\mathrm{SD}_{1}$ & $\overline{\mathrm{X}}_{2}$ & $\mathrm{SD}_{2}$ & & & \\
\hline 1 & $\begin{array}{l}\text { Workshop sessions have introduced } \\
\text { me to new teaching methodologies }\end{array}$ & 3.06 & 1.75 & 3.04 & 1.74 & 3.05 & $1^{\mathrm{st}}$ & High Extent \\
\hline 2 & $\begin{array}{l}\text { Time limitations constrain the } \\
\text { frequency of workshops }\end{array}$ & 2.87 & 1.69 & 2.73 & 1.65 & 2.80 & $8^{\text {th }}$ & High Extent \\
\hline 3 & $\begin{array}{l}\text { Teacher workshop sessions } \\
\text { normally involve segregation to } \\
\text { smaller group sessions for } \\
\text { collaboration }\end{array}$ & 2.86 & 1.69 & 2.88 & 1.76 & 2.87 & $3^{\text {rd }}$ & High Extent \\
\hline 4 & $\begin{array}{l}\text { Workshop is a regular and periodic } \\
\text { activity in your school }\end{array}$ & 2.81 & 1.64 & 2.89 & 1.70 & 2.85 & $5^{\text {th }}$ & High Extent \\
\hline 5 & $\begin{array}{l}\text { Your school conducts mandatory } \\
\text { workshops for teachers. }\end{array}$ & 2.58 & 1.61 & 2.63 & 1.62 & 2.61 & $9^{\text {th }}$ & High Extent \\
\hline 6 & $\begin{array}{l}\text { Your knowledge on specific } \\
\text { subjects have been improved via } \\
\text { workshops }\end{array}$ & 2.94 & 1.71 & 2.78 & 1.67 & 2.86 & $4^{\text {th }}$ & High Extent \\
\hline 7 & $\begin{array}{l}\text { Your communication skills has } \\
\text { improved as a result of a good } \\
\text { workshop session }\end{array}$ & 2.76 & 1.66 & 2.93 & 1.71 & 2.85 & $5^{\text {th }}$ & High Extent \\
\hline 8 & $\begin{array}{l}\text { Your confidence as a teacher } \\
\text { greatly improved as a result of } \\
\text { workshops }\end{array}$ & 3.18 & 1.78 & 2.66 & 1.63 & 2.92 & $2^{\text {nd }}$ & High Extent \\
\hline \multirow[t]{3}{*}{9} & $\begin{array}{l}\text { Funding limitations constrain the } \\
\text { frequency of workshops }\end{array}$ & 2.64 & 1.62 & 3.05 & 1.75 & 2.85 & $5^{\text {th }}$ & High Extent \\
\hline & & 25.70 & 15.15 & 25.59 & 15.23 & 25.66 & & \\
\hline & Aggregate Mean & 2.86 & 1.68 & 2.84 & 1.69 & 2.85 & & \\
\hline
\end{tabular}

The data on Table 1 showed the weighted mean, standard deviation and rank order statistics of school principals and teachers on the extent to which workshop influences teacher productivity in public urban and rural secondary schools in Bayelsa State. The principals and teachers' responses in urban and rural schools showed that all the items have mean values above the criterion mean value of 2.50 and showed that to a high extent, workshop influences teacher productivity in public secondary schools in Bayelsa State.

The rank order statistics showed that conduct of mandatory workshops for teachers and time limitation constraint are ranked very low $9^{\text {th }}$ and $8^{\text {th }}$ respectively. Workshop sessions having introduced the respondents to new teaching methodologies ranked highest (1st); followed by the item that indicated improved confidence of teachers through workshops (2nd).

The data on Table 2 showed the weighted mean, standard deviation and rank order statistics of male and female principals and teachers on how seminar enhances teacher productivity in public secondary schools in Bayelsa State. Male and female principals and teachers' responses showed that items with serial numbers $10,11,12,13,14,15,17$ and 18 have their various mean values above the criterion mean value of 2.50 . The respondents agree to a high extent that seminar enhances teacher productivity in public secondary schools in Bayelsa State. While item with serial number 16 has a mean value below the criterion mean value showing a disagreement by the respondents as how seminar enhances teacher productivity in public secondary schools in Bayelsa State. It was summarized that seminar sessions have introduced teachers to new teaching methodologies although the respondents disagreed that seminar sessions in schools are organized periodically in public secondary schools in Bayelsa State. 
Retraining Programmes for Teacher Productivity in Public Secondary Schools in Bayelsa State: Planning Implications

Research Question 2: How seminar enhances teacher productivity in public secondary schools in Bayelsa State?

Table 2: Weighted mean, standard deviation and rank order statistics of Male and female respondents on how seminars enhance teacher productivity in public secondary schools in Bayelsa State

\begin{tabular}{|c|c|c|c|c|c|c|c|c|}
\hline \multirow[t]{2}{*}{$\mathrm{SN}$} & & \multicolumn{2}{|c|}{$\begin{array}{l}\text { Male principals and } \\
\text { teachers }=150\end{array}$} & \multicolumn{2}{|c|}{$\begin{array}{l}\text { Female principals } \\
\text { and teachers }=217\end{array}$} & \multirow[t]{2}{*}{$\begin{array}{l}\text { Mean } \\
\operatorname{set}\left(x_{1} x_{2}\right)\end{array}$} & \multirow[t]{2}{*}{$\begin{array}{l}\text { Rank } \\
\text { order }\end{array}$} & \multirow[t]{2}{*}{ Remarks } \\
\hline & & $\overline{\mathrm{X}}_{1}$ & $\mathrm{SD}_{1}$ & $\overline{\mathrm{X}}_{2}$ & $\mathrm{SD}_{2}$ & & & \\
\hline 10 & $\begin{array}{l}\text { Seminars have introduced me to } \\
\text { new teaching methodologies and } \\
\text { technologies }\end{array}$ & 3.55 & 1.55 & 3.37 & 1.42 & 3.46 & $6^{\text {th }}$ & $\begin{array}{l}\text { High } \\
\text { Extent }\end{array}$ \\
\hline 11 & $\begin{array}{l}\text { Funding limitations constrain the } \\
\text { frequency of seminars }\end{array}$ & 3.00 & 1.35 & 2.65 & 1.40 & 2.83 & $7^{\text {th }}$ & $\begin{array}{l}\text { High } \\
\text { Extent }\end{array}$ \\
\hline 12 & $\begin{array}{l}\text { Technology limitations constrain } \\
\text { the frequency of seminars }\end{array}$ & 3.88 & 1.44 & 3.45 & 1.47 & 3.67 & $4^{\text {th }}$ & $\begin{array}{l}\text { High } \\
\text { Extent }\end{array}$ \\
\hline 13 & $\begin{array}{l}\text { Infrastructural limitations } \\
\text { constrain the frequency of } \\
\text { seminars }\end{array}$ & 4.00 & 1.56 & 3.57 & 1.55 & 3.79 & $1^{\mathrm{st}}$ & $\begin{array}{l}\text { High } \\
\text { Extent }\end{array}$ \\
\hline 14 & $\begin{array}{l}\text { Academic calendar limitations } \\
\text { constrain the frequency of } \\
\text { seminars }\end{array}$ & 3.97 & 1.53 & 3.38 & 1.42 & 3.68 & $3^{\text {rd }}$ & $\begin{array}{l}\text { High } \\
\text { Extent }\end{array}$ \\
\hline 15 & $\begin{array}{l}\text { Your ICT skills have improved as } \\
\text { a result of seminars attended }\end{array}$ & 3.91 & 1.50 & 3.47 & 1.48 & 3.69 & $2^{\text {nd }}$ & $\begin{array}{l}\text { High } \\
\text { Extent }\end{array}$ \\
\hline 16 & $\begin{array}{l}\text { Seminar sessions in your school } \\
\text { are organized periodically }\end{array}$ & 2.40 & 1.12 & 1.44 & 1.12 & 1.97 & $9^{\text {th }}$ & Low Extent \\
\hline 17 & $\begin{array}{l}\text { There has been remarkable } \\
\text { improvement in your teaching as a } \\
\text { result of a seminar you attended. }\end{array}$ & 2.58 & 1.61 & 2.63 & 1.62 & 2.61 & $8^{\text {th }}$ & $\begin{array}{l}\text { High } \\
\text { Extent }\end{array}$ \\
\hline 18 & $\begin{array}{l}\text { Your knowledge on specific } \\
\text { subjects have been improved via } \\
\text { seminar sessions }\end{array}$ & 3.70 & 1.47 & 3.44 & 1.46 & 3.57 & $5^{\text {th }}$ & $\begin{array}{l}\text { High } \\
\text { Extent }\end{array}$ \\
\hline & & 31.09 & 13.13 & 27.40 & 12.94 & 29.27 & & \\
\hline & Aggregate Mean & 3.45 & 1.46 & 3.04 & 1.44 & 3.25 & & \\
\hline
\end{tabular}

\section{HYPOTHESES}

Hypothesis One: There is no significant difference between the mean scores of urban and rural principals and teachers on the extent to which workshop influences teacher productivity in public secondary schools in Bayelsa State.

Table 3: z-test analysis of the mean scores of urban and rural principals and teachers on the extent to which workshop influences teacher productivity in public secondary schools in Bayelsa State

\begin{tabular}{llllllll}
\hline Category & $\mathrm{N}$ & $\mathrm{X}$ & $\mathrm{SD}$ & $\mathrm{Df}$ & z-cal & z-crit. & Remarks \\
\hline Urban & 237 & 2.86 & 1.68 & 365 & 0.10 & 1.96 & Not-significant \\
Rural & 130 & 2.84 & 1.65 & & & & \\
\hline
\end{tabular}

Table 3 revealed that principals and teachers in urban schools have mean and standard deviation scores of 2.86 and 1.68 respectively while principals and teachers in rural secondary schools have mean and standard deviation scores of 2.84 and 1.69 respectively. With a degree of freedom of 365 at an alpha significant level of 0.05 , the calculated $\mathrm{z}$-value of 0.10 is less than the critical $\mathrm{z}$-value of 1.96 .
Therefore, the null hypothesis was accepted. There is no significant difference between the mean scores of principals and teachers in urban and rural secondary schools on the extent to which workshop influences teacher productivity in public secondary schools in Bayelsa State. 
Hypothesis Two: There is no significant difference between the mean scores of male and female principals and teachers on how seminar enhances teacher productivity in public secondary schools in Bayelsa State.

Table 4: z-test analysis of the mean scores of male and female principals and teachers on how seminar enhances teacher productivity in public secondary schools in Bayelsa State

\begin{tabular}{|c|c|c|c|c|c|c|c|}
\hline Category & $\mathrm{N}$ & $X$ & SD & Df & Z-cal & z-crit. & Remarks \\
\hline Male & 150 & 3.45 & 1.46 & & & & \\
\hline Female & 217 & 3.04 & 1.44 & 365 & 2.51 & 1.96 & significant \\
\hline
\end{tabular}

Table 4 showed that male principals and teachers have mean and standard deviation scores of 3.45 and 1.46 respectively while female principals and teachers have mean and standard deviation scores of 3.04 and 1.44 respectively. With a degree of freedom of 365 at an alpha significant level of 0.05 , the calculated z-value of 2.51 is greater than the critical $z$-value of 1.96. Therefore, the null hypothesis was rejected. By implication, there is a significant difference between the mean scores of male and female principals and teachers on how seminar enhances teacher productivity in public secondary schools in Bayelsa State.

\section{DISCUSSION OF FINDINGS}

The findings of this study showed that seminar sessions have introduced teachers to new teaching methodologies and technologies. In agreement, Ingram (2016) opined that teachers by virtue of attending seminars improve on their productivity. Another finding is that the following constitute barriers to the conduct of frequent workshops and seminars: funding and technology limitations as well as infrastructural and academic calendar limitations. On the other hand, there is a remarkable improvement in teachers' knowledge of specific lessons as a result of a seminars attended. The teachers' knowledge of specific subjects have been greatly improved via workshops and seminars ultimately leading to enhanced teacher productivity in public secondary schools in Bayelsa State.

In line with this finding Adelheid, Manuel, Joanna and Henry cited in Ojekudo (2015) posited that it is the responsibility of schools to ensure that their teachers are up-to-date in latest school programmes therefore the need for retraining of teachers. Furthermore, they emphasized that it is necessary for teachers to undergo retraining programmes because a teacher who does not have proper knowledge of the job expectations, may not be able to integrate adequately into the school system. The result of the second hypothesis showed that there is a significant difference between the mean scores of male and female principals and teachers on how seminars enhance teacher productivity in public secondary schools in Bayelsa State. This implies that both male and female principals and teachers seem not to agree that seminars affect teacher productivity.

\section{CONCLUSION}

Based on the findings of this study, it is concluded that workshops and seminars are inevitable formidable retraining programmes for improved productivity of teachers in public secondary schools in Bayelsa State. The importance of educational planners in ensuring that these programmes feature frequently in the academic calendar cannot be overemphasized.

\section{RECOMMENDATIONS}

Based on the findings, the following recommendations were made:

1. Bayelsa State Government should ensure constant organized retraining sessions for teachers in public secondary schools. And make provision for the required funding to sponsor the training programmes.

2. Vice principal academics and others assigned with the duty of organizing workshops for teachers should ensure that teachers are periodically engaged in various workshop sessions in order for teachers' productivity to be constantly improved.

\section{REFERENCES}

[1] Educational Initiatives Pvt. Ltd. (2010). Capacity Building for Teachers: EI Working Paper Series Issue-13, p.7. Retrieved from http://www.ei-india.com/wp-content/uploads/2012/07/Capacity-Buil ding-for-Teachers-Issue-13.pdf

[2] Federal Republic of Nigeria (2013). National Policy on Education. Lagos: NERDC

[3] Hill, L. (2012). The value of Workshops and Continuing Education for Teachers: The Evollution. Retrieved From https://evolllution.com/ opinions/the-value-of-workshops-and-continuing-education-for-teac hers/

[4] Ingram, P. B. (2016). Icons of Education: Ingram Magazine. Show -Me Publishing, Inc. 2049 Wyandotte, Kansas City, MO 64108

[5] Igwe, L.E.B. (2002). Introduction to Educational Administration. Port Harcourt: Global Link Communication International.

[6] Nkang, I. E. (2012). Basics of Education Supervision. Uyo: Afahaide \& Bros Printing\& Publishing Co.

[7] Ojekudo, B. E. (2016). Teacher's development programmes for effective service delivery in secondary schools in Delta State. Unpublished (Master's thesis), University of Port Harcourt, Nigeria.

[8] Palappallil, D. S., Sushama, J.\& Ramnat, S.N. (2016). Effectiveness of modified seminars as a teaching-learning method in pharmacology: International Journal of Applied and Basic Medical Research, 6(3),195 Retrived from http://www.ijabmr.org/article.

[9] Seminar. (n.d.). Retrieved September 5, 2018, from Wikipedia website, https://en.wikipedia.org/w/index.php?title=Seminar\&oldid $=862423424$

[10] What is a seminar evenues.com (n.d.). Retrieved October 10, 2018, from http://www.evenues.com-event-planning-guide 